\title{
Perspektiver fra tre ph.d.-stipendiater
}

\section{Mainstreaming af 'irrelevante fænomener' - er det muligt?}

\section{Af Eva Bendix Petersen}

$\mathrm{F}$ ilosoffen Judith Butler arbejder som bekendt med begrebet om 'det kulturelt genkendelige'. Begrebet er tænkt til at gribe den grundlæggende præmis ved individets væren i sin verden, nemlig at et vist omfang af kulturel genkendelighed udgør en nødvendig forudsætning for individets kulturelle integration (Butler 1990). Er individet ikke-genkendeligt, opfører vedkommende sig for mærkeligt, for anderledes, indenfor en given kulturel kontekst, så vil vedkommende blive mødt med ekskluderende kræfter fra omgivelserne. Vedkommende vil blive sygeliggjort, stigmatiseret, marginaliseret, eller blot ignoreret - der er tale om modvind i mange udgaver og styrker (Søndergaard 1996).

Begrebet har været nyttigt for mig i forhold til at forstå min proces med at integrere mig på min nye arbejdsplads et ph.d-stipendium ved et ikke-kønsforskningscenter. Der har fra starten ikke været tvivl om mine forbindelser til kønsforskningen og disse forbindelser, har gjort at jeg har måtte udføre en række ritualer for at fremstå som en kulturel genkendelig og værdig kollega. Naturligvis har samtlige af mine kolleger i deres integrationsprocesser også måtte positionere sig som værdige kolleger, men det med tilknytningen til kønsforskningen synes alligevel at afkræve en helt serlig type ritual.

Ritualet handler om at signalere at man er en kulturel genkendelig og værdig forskeraspirant på trods af disse kønsforskningsaffiniteter. At man 'er i stand til at gå på to ben', at man er interesseret $\mathrm{i}$ at ' $\mathrm{kva}$ lificere sig alment', at man 'ikke tænker køn ind i alting'. Det handler kort sagt om at lægge afstand til et ganske bestemt ikon: nemlig kvindeforskerikonet. Ikonet repræsenterer noget kulturelt ikke-genkendeligt, noget uacceptabelt.
Den ikoniserede kvindeforsker er en subjektiv, ensporet, fanatisk anakronisme med en mere eller mindre, mest mindre, skjult (politisk) dagsorden. Hun strider mod forestillingerne om saglig, objektiv, relevant og gyldig videnskabelighed og er dermed selvforskyldt i sin marginalisering. Hun befinder sig i den akademiske ghetto, fordi hun ikke er 'kommet videre', som den faste vending synes at være.

Ikonet er på den måde et udtryk for et ugenkendeligt fænomen ${ }^{1}$ i den akademiske kultur og dette uanset om det nogensinde har haft konkrete kropslige modeller at komme til live igennem. Ikonets præmissættende betydning fungerer uafhængigt om billedet er fortjent eller kan tilbagevises, om det kan dokumenteres at kvinde- og kønsforskningen aldrig har været enøjet (i hvert tilfælde ikke mere end andre discipliner) osv., aldrig selv har villet periferien eller hvad man nu kan tænke sig.

Det kulturelt ugenkendelige ikon har, uanset hvad, betyd- 
ning for hvordan sådan nogle som jeg må færdes, hvordan vi må begå os og hvilke ritualer vi må udføre på de sociale arenaer, hvor ikonet om den kulturelt ugenkendelige kvindeforsker hersker. Ikonet giver særlige præmisser for positionering - og det skal tilføjes at den specifikke arena jeg befinder mig på ikke er særligt ekstrem eller anderledes end andre i forhold til det her ikon.

Nuvel, jeg har spekuleret på hvordan jeg nu skulle håndtere denne forbindelse mellem mig og den her ikoniserede forestilling. For der var ingen tvivl om, at jeg ikke kunne lade lighedstegnet stå, hvis jeg ønskede integration og værdighed. Et par gange så jeg mig selv udføre nogle besynderlige ritualer, jeg var for eksempel flink til at fortælle at mit nuverende projekt, det jeg er blevet ansat på, ikke er et kønsforskningsprojekt. Men hvad var det nu for et ritual, hvad var nu det for en strategi? Ønskede jeg virkelig at lægge den forventede afstand til ikonet på denne måde og hvad betød det, at jeg gjorde det? Betød det, at jeg genskabte forestillingen om at de der beskæftiger sig med køn altid kommer i utroværdige og uværdige udgaver? Betød det, at jeg fik reproduceret forestillingen om køn som et uværdigt og irrelevant forskningsobjekt? Og hvorfor var det den strategi jeg valgte at samle op og gøre til min egen?

Det kan der være mange grunde til, men én af grundene er, at det er den umiddelbart tilgængelige. Den strategi der ligger ligefor er den der hedder 'se, jeg er kommet videre! Køn udgør måske en lille bitte dimension af det jeg beskæftiger mig med, men jeg er også en ordentlig forsker, jeg er ikke subjektiv, fanatisk eller insisterende eller noget, bare med selve genstandsfeltet køn, at gøre.

Den herskende forestilling synes nemlig at være, for det første, at køn ikke er et rigtig relevant og gyldigt forskningsfelt, og for det andet, at køn i

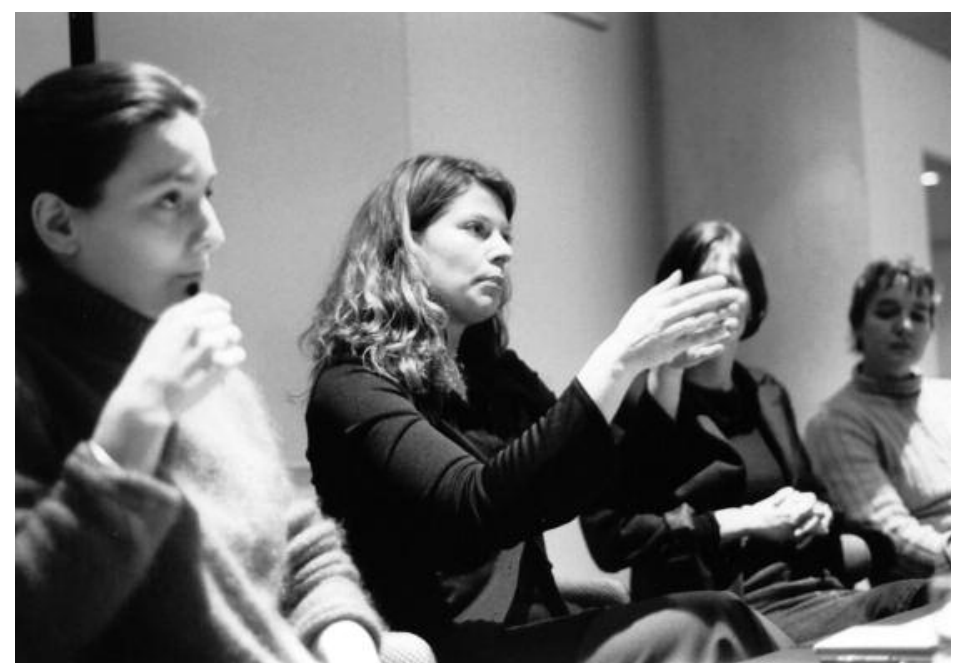

Eva Bendix $i$ midten.

rolig'. For man lærer jo hurtigt at det at interessere sig for $\mathrm{k} ø \mathrm{n}$, det at bringe $\mathrm{k} ø \mathrm{n}$ ind som parameter i gode og gyldige videnskabelige samtaler om legitime emner, sender dig lige lukt ud på grænsen til det kulturelt ugenkendelige. Og afkræver dig særlige positioneringsritualer og de er opslidende i længden.

Tanker og erfaringer som disse gør at jeg bliver lidt halvluren når vi taler om mainstreaming af køn og kønsforskningen ind i den her specifikke kontekst, videnskabssamfundet, og det har lidt med kvindeforskerikonet, men også det hele taget intet betyder; hverken for vores evner som forskere, vores kvalifikationer, vores interesser (Bendix Petersen 1999, Vestergaard et. al. 1998). Forskere er mennesker, individer, personer, der besidder en række faglige kompetencer og kvalifikationer. $\mathrm{Og}$ disse kompetencer og kvalifikationer har intet med forskerens køn at gøre. Netop derfor, synes den herskende forestilling at være, er det forkert at kønskvotere, det er helt hul i hovedet at kreve at der skal sidde kvinder i bedømmelsesudvalg osv., for deres bedømmelseskompetencer har absolut intet, 
eller burde intet have, med deres køn at gøre, og hvorfor skulle man i øvrigt tro, at kvinder ville være garanter eller vogtere for at der ikke går Rip, Rap og Rup i den?

Forestillingen er: Køn har ingen betydning og bør ingen betydning have. For videnskabssamfundet er et elitesystem, der bygger på elitekriterier, hvilket vil sige at vi udelukkende rekrutterer efter faglige kvalifikationer (Henningsen 1999). Hvis vi begynder at kønskvotere og den slags vil elitesystemet jo falde fra hinanden, så vil man jo kunne begynde at inddrage helt andre parametre og kriterier - for hvis vi begynder at tænke noget så omsonst og irrelevant ind som forskernes køn, ja så kunne vi lige så godt gå hele vejen og begynde at foretrække folk efter hårfarve eller sige, at vi kun vil have dem ind der bor i Københavns Nordvest kvarter - og falder vi af på vores håndhævelse af det elitære, det faglige, ja så er det også sket med selve universitetets berettigelse som institution i dette samfund.

Det er den type ræsonnementer der synes at være de fremherskende og det er sådanne typer ræsonnementer man må forholde sig til når man tænker køn og mainstreaming i forskersamfundet, og når man positionerer sig som forskeraspirant med affiniteter til kønsforskningen. Og det der har været det mest påfaldende for mig i forhold til dagens øvrige diskussioner, har været den mangel på anerkendelse af dette frnomens omfang og betydning. Jeg er dybt forundret over den manglende refleksion over vores, kønsforskningens, grundlæggende problem: Genstandsfeltets 'irrelevans' og medfølgende ekskluderingsprocesser. Vi står indigneret og konstaterer at ungdomsforskningscentre og turismeforskningscentre knopskyder imens kønsforskningen udmarves (Sjørups oplæg), vi peger indigneret på de forskningspolitiske prioriteringer der finder sted og som virker kønsskævvridende (Henningsens oplæg), vi konstaterer forurettet at der indenfor sundhedsvidenskaben ikke forskes i kvindekroppe og -helse (Pettersons oplæg), at der ikke tænkes køn ind i fordelingen af stipendier etc. etc. Men hvordan kan vi blive ved med at forundres? Hvordan kan vi blive ved med at være så indforstået med vores egen indignation, at vi remser uretfærdigheder op for os selv og hinanden, mens resten af verden står og griner af os? Jeg trækker det hårdt op nu, men jeg er ærlig talt lidt forundret over den manglende villighed til at se hvilke typer kræfter vi her har med at gøre.

Jeg spørger om mainstreaming af "irrelevante fænomener" er muligt, fordi jeg ønsker at sætte fokus på netop denne herskende kulturelle forestilling om netop køn som urovækkende, irrelevant og problematisk forskningsobjekt, og som irrelevant rekrutteringskriterium. Jeg ønsker at spørge hvordan vi făr indtænkt køn som noget værdigt og gyldigt at beskæftige sig med (og her er det vigtigt at pointere at spørgs- målet også gælder andre 'irrelevante fænomener')? Både forskningsmæssigt og i forhold til rekruttering? Hvordan får vi gjort køn synligt og relevant i en kontekst der forstår sig selv som kønsneutral? Og kunne det tænkes, at det lige præcis var i forestillingen af sig selv som kønsneutral, at der ligger forskellige betingelser og muligheder for kønnene i systemet? Hvilke konsekvenser har de forskellige mulige strategier for synliggørelse af kønnets betydning? Og hvad er det for en kamp der egentlig kæmpes? Er det noget med fastholdelse af en type 'universitetssystem' og 'videnskabsforståelse' overfor en anden, og er vi selv villige til at betale prisen for den udfordring af elitekontruktionen vi igangsætter når vi eksempelvis foreslår at køn skal indtænkes aktivt i rekrutteringen af videnskabeligt personale?

Min pointe er altså, at så længe køn har den urovækkende og irrelevante status som det har, så giver det nogle helt særlige betingelser at mainstreame på, betingelser som vi må forholde os til, som vi ikke kan ignorere. Vi risikerer, at strategien kommer til at virke som fremmedlegeme, som monstrøsitet, som et kulturelt ugenkendeligt fænomen, der ikke vil opnå den ønskede gennemslagskraft og effekt, måske endda tværtimod, gøre det endnu sværere at tale om køn og endnu sværere at legitimere sin forbindelse til kønsforskningen.

Men betyder det her så, at vi lige så godt kan opgive æured, at vi skal spille med og godtage historien om det irrelevante 
køn? Er det det jeg siger?

$\mathrm{Nej}$, men jeg foreslår at de mainstreamstrategiske initiativer tænkes helt ud i deres konsekvens og kobles sammen med visioner for forskning, for kundskabsgenerering og dennes institutionelle forankring hvad er det for et universitetssystem og en type forskning vi ønsker os, hvad er det videnskab og forskning skal biddrage med og hvilken type status skal denne type kundskabsproduktion have? Hvad er det for en type forskning kønsforskningen evt. skal mainstreames ind $\mathrm{i}-\mathrm{og}$ giver det overhovedet mening, at tale om andre discipliner som noget kønsforskningen kan integreres i? Der mangler nogle overvejelser om hvad forskningen skal og kan, og subsidiært hvad kønsforskningen skal og kan, i de her snakke om mainstreaming.

Samtidig fastholder jeg at en evt. mainstreaming må og skal sammentænkes med andre kulturændrende bestræbelser. For at kunne mainstreame må køn på dagsordenen, det må føles vedkommende og relevant

(Og det er denne pointe som det er gået op for mig, at jeg burde have kommenteret mere på, for vi er åbenbart ikke helt enige om hvad det betyder og hvilke strategier vi tænker i forhold til det, så spørgsmålet er: Hvordan - med hvilket formål og midler - ønsker vi at synliggøre køn?). Én måde, fastholder jeg, er at få synliggjort at mænd også er kønnede individer. Søren Ervø foreslog i sit oplæg at vi anvender maskulinitetsforskningen som en Trojansk hest, et implosions-in- strument til at få kønsforskningen kørt i stilling som relevant - også for mænd. Det kan meget vel tænkes at være en strategi der vil virke.

Under alle omstændigheder synes jeg at opleve, at det er muligt at få køn på dagsordenen hos både mænd og kvinder, når man introducerer de konstruktivistiske tanker om køn som en relation, som noget samtidigt flydende og stabiliserende, og som noget vi alle sammen forhandler hele tiden. Forhandlingsaspektet făr 'kampen' om kønnene særdeles nærværende.

Og den her optagethed af at få mændene med handler ikke om ambitioner om at være en pæn pige i det gode selskab, det handler om et teoretisk grundperspektiv som er opmærksom på første- og andethedsstatusser. Jeg bliver vred når mine synspunkter og strategier reduceres til netop at handle om at være pæn og den slags ... Jeg vil have persillen ud af ørerne på folk, nå ud over bordkanten - men det er ikke det samme som at gøre sig til.

Jeg tænker mig synliggørende og kulturændrende bestræbelser på mange niveauer og $\mathrm{i}$ mange former. Jeg udelukker ikke at det kan være gavnligt at opremse og dokumentere uligestilling, barrierer og skxvheder - at bekræfte os selv og hinanden $i$ at det 'sgu er for dårligt' - men vi skal tage betingelserne, stigmatiseringen, alvorligt og lytte godt efter hvad der er på spil når historien om kønnets irrelevans (gen)fortælles.
Personligt foretrækker jeg at skabe moddiskurser der hvor jeg nu kan komme til det. Og jeg vil helst skabe dem sammen med andre der har samme mål; det er ikke nødvendigvis kvinde- og kønsforskere, men kan meget vel tænkes at være etnicitetsforskere, (homo)seksualitetsforskere etc., forskere der lige som jeg ønsker at bedrive 'undergravende forskning' som Nina Lykke udtrykte det i sit oplæg. For denne 'undergravende forskning', som 'the inappropriate others' foretager, har som intention at forandre de magt/videnrelationer der betyder at vi kan fortælles frem som 'undergravende', betyder at vi og vores genstandsfelt kan kategoriseres som irrelevante, uværdige, ugyldige, illegitime. Mine bestræbelser for at ændre aktuelle magtkonfigurationer bevæger sig måske på grund af sine strategier og mål på såvel videnskabssamfundets som dele af kvinde- og kønsforskningsmiljøets grænser for det kulturelt $\mathrm{u} /$ genkendelige; spørgsmålet er imidlertid om det ikke er denne type grænsevaklende forandringsintention, der for alvor har noget af det der skal til for at sætte fut i fejemøget.

\section{Noter}

1. Judith Butlers begreb 'cultural intelligibility' som jeg her oversætter til 'det kulturelt genkendelige', er også oversat til 'det kulturel forståelige' eller 'det kulturelt acceptable' (Søndergaaard, 1996). Det skal i denne forbindelse understreges at der ikke er modsætning mellem at være ikke-genkendelig og at være et 
ikon. Man kan godt ikonisere noget ikke-genkendeligt, i betydningen ikke-acceptabelt.

\section{LITTERATUR}

- Bendix Petersen, Eva (1999): Kon, Virksombed \& Kompetence - en destabiliserende diskursanalyse af videnskabssamfundets konnede konstruktioner, Køn i den Akademiske Organisation, Arbejdspapir, nr. 6 .

- Butler, Judith (1990): Gender Trouble: Feminism and the Subversion of Identity, Routledge, London \& New York.

· Henningsen, Inge (1999):

"Om kvalifikationer og køn", i Kvinder, Kon \& Forskning, nr.l.

- Søndergaard, Dorte Marie (1996): Tegnet på Kroppen-

Køn: Koder og konstruktioner blandt unge voksne i Akademia, Museum Tusculanums Forlag, Københavns Universitet.

- Vestergaard, Elisabeth og Michael Taarnby (1998): Forskning i forskningsmidler - Ansøgere til Statens Sundhedsvidenskabelige Forskningsråd, Analyseinstitut for Forskning, Rapport nr. 2.

\section{Eva Bendix Petersen}

phd.-stipendiat

Sociologisk Institut, $K U$
Imellem isolation og networking: Kønsforskning på Syddansk Universitet

\section{Af Lotte Nyboe}

$\mathrm{N}$ år jeg har kaldt mit oplæg "Imellem isolation og networking" er det for at understrege to af flere kår for en yngre dansk kønsforsker som mig i dag. Jeg er ansat ved Institut for Litteratur, Kultur, Medier under Center for Kvinde- og Kønsstudier, dvs. jeg er centertilknyttet og det er den position, jeg taler ud fra. Jeg er videre del af projektet "Kyborger og cyberspace - imellem narration og socioteknisk virkelighed" - et projekt, der blev en realitet med støtte fra Forskningsrådets FREJA-midler, der blev uddelt i slutningen af 1998. Hvor jeg i projektgruppen er del af et tværfagligt og tvær-institutionelt netværk, samtidig med, selvfølgelig, at være del af forskellige emne-relaterede fjernnetværk, sidder jeg i universitetssystemet mere isoleret. Jeg er den eneste ph.d'er ved centeret, min vejleder Nina Lykke er af gode grunde sjældent på stedet, efter hun blev ansat i en professor-stilling i Sverige, og de øvrige ansatte ved centret der tæller en lektor, en amenuensis og tre løst ansatte - har ingen betydelig daglig kontakt. Samtidig er der indenfor Syddansk Universitets mure ikke tradition for, i det daglige, at kommunikere på tværs af faggrænser. Opdelingen i fakulteter, institutter, og centre og den adskillelse og isolering der er af de enkelte forskningsom- råder, afspejles naturligt også hos ph.d'erne ved instituttet, og det vi har sammen begrænses til en ansøgning om at få lov til at bruge nogle af vores rejsepenge til bøger i stedet. Her skal jeg pointere, at jeg udemærket godt forstår, hvorfor murerne er så svære at skræve over. Jeg forstår barriererne, fordi jeg er barn af institutionen og er skolet indenfor denne universitetstradition. Jeg har igennem min opvækst ved institutionen lært at "hver ting til sin tid". Ligesom man skal passe på med at blande alkohol, må man være forsigtig med at blande teoretiske paradigmer, forskningsdiscipliner, m.v. Eventuelle blandingsforhold må være nøjagtige og understøttede.

Kønsforskningen har her fungeret som en underfundig trickster for mig, fordi det indenfor et bredt udsnit af de kønsforskningsrelaterede paradigmer er en naturlig og nødvendig omstændighed at arbejde på tværs af discipliner og paradigmer. På ransagende og selvreflekterende vis har jeg i årerne, hvor jeg har beskæftiget mig med køn, arbejdet på at løsne op for de knudepunkter, hvor jeg stagnerer i paradigme-frygt - et arbejde, der har bevirket en bevægelse imod nye egne, indenfor primært, for mit vedkommende, lingvistik og kommunikationsteori. Feltet Cultural Studies italesætter denne opløsning, som jeg har arbejdet med. Dets metodologiske tiltag, der ofte betegnes bricolage, med Claude Levi-Strauss' begreb, henviser til måden mennesker bringer forskellige objekter el- 
ler fænomener sammen for at udvikle og assimilere ideer. Bricolage kan som metode kontrasteres til den postindustrielle verdens traditionsbundne forskning og forskningsstrategier generelt. Cultural Studies er både inter- og anti-disciplinær og trækker på discipliner og videnspraktikker relevante eller nødvendige for at generere den viden, der er behov for i relation til enkelte projekter. Valg af forskningsstrategi eller strategier vil afhænge af spørgsmålene stillet, og spørgsmålene vil videre afhænge af deres specifikke kontekst eller kontekster. Brikolører bruger, kort sagt, hvad de har ved hånden.

I diskussionen af mainstreaming af kønsforskning mener jeg at Cultural Studies illustrerer en vigtig pointe mht. networking og bricolage som strategi. Kønsforskningen vil potentielt nyde gavn af at indgå i mere konkrete sammenhænge med et bredt felt af discipliner i det daglige. Samtidig kunne jeg også ønske en mere specifik situering af køn som kulturelt fanomen og ikke udelukkende politisk fonomen, der opretholdes med bevarelsen af "kvinde" i "Center for Kvinde- og Kønsforskning" og "Foreningen for ... osv.". Her bevæger jeg mig ind i farefuldt farvand, fordi der i en sådan bevægelse er risiko for, at det kønspolitiske falder i baggrunden. Jeg mener det ville være både trist og meget problematisk, hvis de kønspolitisk spørgsmål vedrørende ligestilling, m.v. blev perifere spørgsmål, men omvendt trænger fænomenet køn og kønsforskningen til et hamskif- te. Dette behov eksisterer, fordi dét at diskutere køn ikke kun handler om politik, ligestilling, urimelighed, og utilfredshed - dét handler det ogsa om, men det handler i lige så høj grad om køns gennemsyrende effekt som social og kulturel faktor i en mangfoldighed af kontekster, der ikke nødvendigvis begrænser sig til noget kønspolitisk. For mig handler køn heller ikke kun om forskellighed men også enshed - en dimension der ofte forsvinder helt ud af billedet i centreringen af forskellighed. Associationen imellem fænomenet køn og utilfredshed skråstreg vrede kvinder manifesterer sig både i medierne, hvor senest "Fisseflokken" har vagt opmærksomhed, men også i menneskers mere konkrete forståelse af steder som Kvinde- og Kønsstudier på Syddansk Universitet. Hvordan kan eksempelvis sætningen "jeg læser Køn og Kultur" udsagt i hverdagslig sammenhæng - ellers afføde spørgsmålet "hader du så mænd?"

Køn og videre kønsforskningen repræsenterer samtidig for mange noget ganske irrelevant, fordi det er manges opfattelse at kvinder har ligestilling. Tør øjnene og kom i gang, lyder budskabet fra mænd og kvinder samtykkende. Det er vigtigt at fastslå, at de kønspolitiske spørgsmål stadig har relevans, at ligestilling ikke er en sluttet proces, men isolationen af de kønspolitiske spørgsmål til enkelte centre mener jeg ikke er vejen frem i dag. Hvis forståelsen er, at køn kun handler om ligestilling, der jo er irrelevant fordi vi har det, så må vi være bedre til at illustrere, hvordan køn indgår i en mangfoldighed af sammenhænge med stor relevans for mange mennesker samtidig med at spille en afgørende rolle for, hvordan vi som mennesker, mænd og kvinder, er stillet $\mathrm{i}$ forhold til hinanden. Det handler om, at tematisere køn som det kommer til udtryk i dets mange afskygninger i kulturen og forskellige delkulturer, som en multipel og variabel faktor, der er del af vores daglige performances, uden at køn i denne tematisering nødvendigvis problematiseres.

Denne dobbelthed - anerkendelsen af det kønspolitiske og det problematiske $i$ at isolere kønsforskningen - illustrerer, hvad jeg fristes til at benævne, den yngre kønsforskers paradoks, uden selvfølgelig at skulle gøre mig til talskvinde for, hvad alle yngre kønsforskere tænker og føler. Paradokset indeholder modsxtningen, at se relevansen $i$ at fastholde kvinder som målgruppe og det primære fokus for forskningen, at anerkende arven og feministernes værk, men så, på den anden side, at have lysten til at ændre fokus, at mainstreame køn så det indgår som en integreret og ikke isoleret faktor på tværs af centre, institutter, fakulteter, institutioner, m.v. Mit paradoks indeholder konkret betoningen af networking fremfor isolerede kønsforskningscentre.

Det jeg her lidt poppet kalder networking, er et grundlæggende eksistenvilkår for den yngre kønsforsker i akkumulationen af viden og inspiration, fordi de fysiske miljøer er små og relativt ringe stillede. Søg- 
ningen $u d$ er fundamental, fordi feltet er snævert. Både teoretisk men bestemt også praktisk dygtiggøres man derfor, som centertilknyttet yngre kønsforsker, i at arbejde på tværs og at arbejde i mangfoldige sammenhænge. Den ny informationsteknologi og computermedierede kommunikationssystemer har gjort det meget favorabelt at networke på fjern-distancen, men den fysiske lokalitet og ens fysiske situerethed i enkelt miljøer, me-

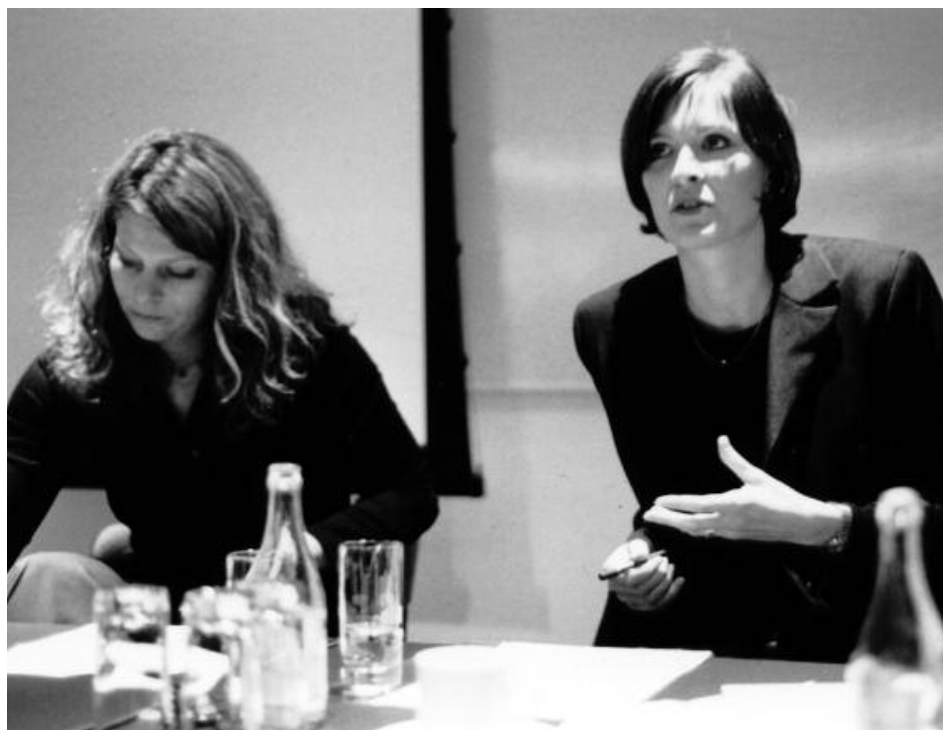

Lotte Nyboe til hojre.

ner jeg dog, er lige så vigtig. I stedet for at det her bliver et spørgsmål om nærvær versus fjernvær, vil jeg snarere rette opmærksomheden imod, hvordan man på de individuelle institutioner får skabt nogle spændende uddannelses- og forskningsmiljøer på lige fod med en opretholdelse af eksterne netværk. Viden og forsk- ning produceres også, i en lidt forenklet vending, ved kopimaskinen eller på toilettet, i de daglige dialoger med ligesindede og uligesindede, men sådanne miljøer behøver ikke at være centreret til kønsforsknings-disciplinen.

Mainstreaming af køn handler derfor, efter min mening, ikke om at skabe fjern-værk $p a$ bekostning af nærmiljøet men om at få lagt køn ind i en sammenhæng, hvor det ikke eksisterer som isoleret fænomen sammenlægge et center som "Kvinde- og Kønsstudier" på Syddansk universitet med Kulturstudier, ligesom de har gjort det i Århus med sammenlægningen af Cekvina og Europæiske Kulturstudier. Målet skulle selvfølgelig først og fremmest være en styrkelse af kønsforskningen, men yderligere vil den sociale berøringsflade for centrets medarbejdere også blive styrket med en sådan omlægning. Nogle akademikere kunne måske drømme om isolationen som medium for fordybelse, som yngre kønsforsker synes jeg ikke isolationen er noget man bør efterstræbe men snarere afværge.

Det er vanskeligt om end ikke umuligt at overskue konsekvenserne af en generel mainstreaming af kønsforskningen, men jeg tror kønsforskningen gør sig selv en bjørnetjeneste ved at insistere på en opretholdelse af centrene i deres gamle form og ordet "kvinde" $i$ "Kvinde- og kønsforskning". Kønsforskere skal stadigvæk studere kvinder og kvinders kår i både socialt og politisk lys, men fænomenet køns til tider heftige stigma i vores nutidige kultur anno 2000, hvor næsten lige så mange kvinder som mænd stejler, når man siger køn, må tages alvorligt. Stigmatiseringen bevirker bl.a. at færre yngre danske studerende vælger at tage et sidefag i "Køn og Kultur", hvilket kan have konsekvens for centrets overlevelse i systemet. Uden "Køn og Kultur" på Syddansk Universitet vil studerende ved Danmarks tredjestørste universitet ikke kunne erhverve sig kundskaber indenfor kønsteori 
fordi der ikke udbydes fag ved andre institutter eller centre end Center for Kvinde- og Kønsstudier. Hvis kønsdimensionen bliver lagt ind bredt ved forskellige centre, institutter og fakulteter, mener jeg, at der er god grund til at tro, at denne mainstreaming vil have en positiv afsmittende effekt på køn som begreb og fænomen. Hvis kønsforskningen kommer til at signalere noget andet og mere end en kønspolitisk dagsorden, så tror jeg, at det for fremtiden vil blive nemmere at forske i køn inklusive de kønspolitiske spørgsmål fordi interessen er større og stigmatiseringen mindre.Hvis kønsforskningen kommer til at signalere noget andet og mere end en kønspolitisk dagsorden, så tror jeg, at det for fremtiden vil blive nemmere at forske i køn inklusive de kønspolitiske spørgsmål fordi interessen er større og stigmatiseringen mindre.

Lotte Nyboe, ph.d-stipendiat, Center for Kvinde- og konsstudier, Syddansk Universitet, Odense

\section{Segmentering eller frigørelse?}

\section{Af Ulla Højmark Jensen}

$\int_{\text {Seg }}$ eg er ph.d.-stipendiat på Institut for Statskundskab i København. Jeg arbejder med et forskningsprojekt der handler om unge og politisk kultur og jeg skal være færdig i slutningen af året.

\section{Min placering uden for centrene}

Jeg er ikke tilknyttet noget kønsforskningscenter eller direkte del af et større kønsforskningsprojekt. Men jeg har været så heldig at blive løst tilknyttet et tværuniversitært forskningsprojekt: GEP projektet ("Gender, Empowerment and Politics") og jeg har derigennem fået en meget dygtig kønsforsker, AnnDorthe Christensen, som min bivejleder. Og så sidder jeg $\mathrm{i}$ øvigt i redaktionen for tidsskriftet Kvinder, køn \& forskning.

\section{Kønsforskningens prestige}

Hele min studietid fra 1982 til 1992 har jeg beskæftiget mig med køn på forskellig vis. Jeg har læst på tre forskellige universiteter så jeg tror jeg ved hvad jeg taler om når jeg konstatere at kønsforskning ikke er prestigefyldt at beskæftige sig med. Ud over alle de små nedladende kommentarer og hentydninger man făr fra kvindelige og mandlige kolleger, kan den manglende prestige også komme direkte til udtryk. Som for eksempel da jeg var ved at skrive min ph.d.-ansøgning og jeg på gangene på mit institut fik at vide - helt uformelt selvfølgelig - at hvis køn var omdrejningspunktet i min ph.d.ansøgning ville det være meget tvivlsomt om den ville gå igennem.

\section{Jeg vil ikke sættes $\mathrm{i}$ bås} men jeg vil støttes i et kønsperspektiv

Jeg er ikke selv vild med at blive sat i bås. Jeg opfatter mig selv som humanistisk samfundsforsker med særlig interesse for at synliggøre uretfærdigheder og forstå mangfoldigheder, og i det arbejde er køn ofte en relevant struktur at medtage. I mit arbejde bruger jeg de teoretiske retninger der passer med det jeg laver og jeg har sjxldent oplevet at det har været særlig udbytterigt at lægge sig fast på kun et perspektiv.

Min pointe er derfor dobbelt: På den ene side ønsker jeg ikke selv at blive sat i bås som udelukkende kønsforsker og ikke andet, men på den anden side vil jeg forbeholde mig ret til at beskæftige mig med køn når jeg synes at det er relevant, og jeg vil gerne have vejledning og opbakning til at gøre det. Og det făr jeg ikke nødvendigvis - i min hverdag føler jeg mig ofte meget fagligt isoleret i forhold til mit kønsperspektiv.

\section{Centrenes funktion}

Her har centrene for mig haft en central funktion. Jeg har vidst hvor jeg kunne henvende mig hvis jeg ønskede at deltage i kurser/foredrag eller gerne vil modtage noget vejledning. Hvis kønsforskningsekspertisen sidder spredt er det svære at vi- 
de, hvor man skal henvende sig. Jeg har på centrene oplevet glæden ved at være sammen med interessemæssigt ligesindede. Det er uundværligt $i$ et universitetsmiljø indimellem at føle sig forstået og ikke behøve at forklare og forsvare hvorfor man arbejder med køn.

Det er selvfølgelig vigtigt at få godt fodfreste på de enkelte institutter og processen er da også i gang, men det er ikke frugtbart forskningsmæssigt at bruge for meget tid på at forsvare hvorfor man overhovedet synes at køn er interessant. Jeg har oplevet at nogle højt uddannede forskere på mit institut i diskussionen af et konkret kønsforskningsprojekt så at sige bakker tilbage til Adam og Eva niveauet. At bruge et forsknings fremlæggelsesmøde på at diskutere om der er forskel på kvinder og mænd, det er deprimerende og ikke forskningsmæssigt frugtbart. Dog er det også min erfaring at gode konkrete kønsforskningsprojekter kan høste høj faglig anerkendelse, mens mere abstrakte diskussioner om kønsforskningens betydning og placering inden for institutter og faglige retninger har en tendens til at afføde megen aggressivitet, fordomme og mis- billigelse, fra både kvindelige og mandlige kolleger.

Her er det også vigtigt at pointere at hele mainstreaming-ideen forudsætter at der er en vis ligeværd mellem de forskellige forskningsområder, og så længe den ikke eksistere vil en nedlæggelse af kønsforskningscentre være meget uheldig.

\section{Kønsforskningen skal hele tiden være $\mathrm{i}$ dialog og forny sig}

Jeg ser en stor fare i at kønsforskningen fokuser mere på at bevare sig selv end på at udvikle sig. Så er den for alvor dødsdømt. Det alt afgørende er jo at der hele tiden kommer nye kræfter til - unge mænd og kvinder som også synes at det er deres liv og deres interesser kønsforskningen handler om, så de til sin tid kan overtage. Det er meget godt med styringen for oven, men hvis bunden - de studerende - ikke interessere sig for de spørgsmål som kønsforskningen tager op, så er det hele et fedt. Derfor er dialog central. Dialog mellem top og bund og dialog mellem fagene og forskellige forskningstraditioner.

\section{Behøver man kun satse på én strategi?}

Jeg kan godt forestille mig, at man med fordel $\mathrm{i}$ vores IT tid kunne nøjes med at have et ressourcestærkt kønskoordinationscenter der ville kunne udgøre et udmærket alternativ i forhold til at sikre vejledningsmuligheder og koordinere seminarer og foredrag m.v., men i forhold til at sikre et frugtbart forskningsmiljø tror jeg ikke man ville kunne undvære den nuværende form for centre - endnu. Derfor bliver man nødt til at satse på begge strategier - både centre og mainstreaming.

Men derfor kunne man godt nytænke centrenes struktur. Hvis man arbejder ud fra subsidaritets princippet så er det på institut- og fagområdeniveau der skal være ressourcer til at have kønsforsningsnetværk og samarbejder. Det er vigtigt ikke at lukke sig om sig selv hvis kønsforsknings centrene og samarbejdet skal holdes åbne for de unge kvinder og mænd. Kønsforskningen skal i sit sigte være nytænkende og frigørende, ikke segmenterende.

\section{Ulla Højmark Jensen, ph.d.-stipendiat}

Institut for Statskundskab Københavns Universitet 